\title{
Adelina Emilia Mihali, Toponimie maramureșeană. Valea superioară a Vişeului, Editura Mega, Cluj-Napoca, 2015, 255 p.
}

\author{
Dinu Moscal* \\ Institutul de Filologie Română „A. Philippide”, Str. Th. Codrescu 2, 700481 Iași, România
}

Lucrarea noii cercetătoare de la departamentul de dialectologie și onomastică al Institutului de Lingvistică și Istorie Literară „Sextil Pușcariu” din Cluj se circumscrie unui demers mai larg, reprezentat și prin alte cîteva contribuții dedicate toponimiei județului Maramureș. Acestea din urmă sînt prezentate în introducere (p. 17-20). Urmează un scurt istoric al cercetărilor de toponimie românești, dar și a celor de onomastică şi a celor lexicografice cu relevanță în domeniul toponimiei (p. 21-30), metodologia cercetării (p. 31-33) și un capitol mai amplu, dacă ne raportăm la cele anterioare, care cuprinde considerații de ordin istoric și geografic (p. 34-54). Capitolul al patrulea-glosarul toponimelor din zona indicată în titlu, adică a localităților Borșa, Moisei și Vişeul de Sus (care include și Vișeul de Mijloc)— reprezintă partea de bază a lucrării (p. 55-175). În capitolul al cincilea (p. 176-221) autoarea propune o clasificare a toponimelor, iar în cel final (p. 222-227) sint prezentate particularităţile lingvistice specifice dialectului maramureșean reflectate în toponimele din glosar.

Aria geografică restrînsă avută în vedere arată că toponimele majore reprezintă un procent foarte mic din întregul glosar. Însă microtoponimia oferă cercetătorului posibilitatea de a contura o imagine a comunității dintr-o perspectivă internă (directă), prin numele date realităţilor socio-geografice din spațiul locuit de comunitatea însăşi. Autoarea volumului punctează această deschidere pe care o oferă studiul microtoponimiei, chiar dacă accentuează acest aspect la nivelul descriptiv: „omul [...] selectează din multitudinea de termeni ai limbii pe care o folosește acele cuvinte care corespund cel mai bine însușirii remarcate a unui punct din teren. Aspectele geografice, istorice $\langle$ sic! $>$ ale locului se pot schimba în decursul timpului, dar toponimul dăinuie peste ani și stă dovadă pentru caracteristicile mediului înconjurător, pentru schimbările sociale și politice, pentru contactul lingvistic, migrații, evenimente istorice" (p. 17, cf. și p. 22, 31).

Microtoponimia nu are un statut științific delimitat în cadrul toponimiei, așa cum îl are microistoria în cadrul istoriei; ea se diferențiază de toponimie doar prin materialul supus analizei (toponimele minore), însă la nivel metodologic se impune ancheta, de preferat directă, aşa cum este cazul și pentru lucrarea de față. O parte din considerațiile din capitolul al treilea constă din informații despre realități sociale, geografice, istorice sau economice reflectate în toponimie, precum: T,ipțterai (care este adaptarea germ. Zipserei, nu un derivat cu un presupus sufix rom. ${ }^{*}$-ai; vezi s.v., cf. și p. 216, 219), Pasul Prislop, Borcut, Vinişorul; Preluca Tătarilor, Jgheabul Tătarilor; Borșa Handal, Gura Băii. Desigur, explicațiile etimologice pentru microtoponime ridică adesea dificultăţi, deoarece nu toate motivaţiile au avut o importanţă majoră, aşa cum sînt cele legate de toponimele tocmai menționate.

Conturarea unei imagini social-istorice şi economice a comunității din perspectiva microtoponimiei implică însă multe elemente de istorie locală, acestea reprezentînd şi sursele de bază pentru identificarea etimologiei majorității microtoponimelor. Dificultatea este resimțită în cazul unei etimologii toponimice, care presupune justificarea raportului dintre semnul lingvistic (apelativul sau numele propriu care stă la baza toponimului) şi realitatea (socio-)geografică desemnată. Distincția între etimologia toponimică și cea lingvistică a toponimelor este făcută de Moldovanu (1972, p. 75), studiu de altfel citat în lucrarea prezentată aici. Spre deosebire de etimologia toponimică, cea lingvistică indică apelativul sau numele propriu de la baza toponimului, dar fără a indica și motivația raportului dintre acel apelativ sau nume propriu și realitatea

*Adresă de corespondență: dinu.moscal@gmail.com. 
(socio-)geografică desemnată. Observații în acest sens se găsesc și la geograful Conea (1969, p. 246), care distinge între „originea lingvistică” a unui toponim (adică cuvîntul de la baza unui toponim) și motivația denominării prin respectivul cuvint. Din perspectiva acestei distincții, explicațiile etimologice din glosar se axează pe partea lingvistică, de unde se continuă cu etimologia lexicală, acest traseu fiind propriu-zis implicit la nivel de metodă. Concret, în cazul toponimelor descriptive se indică apelativul de origine, după care se trece strict în planul lexical, prin indicații etimologice privitoare la apelativul respectiv, ca în exemplul de mai jos:

LA CRUCE [la crúčă ], arătură (Borșa). Et.: prep. $l a+$ subst. cruce (< lat. crux, $-c i s)$.

Într-un astfel de caz, o etimologie toponimică ar fi necesitat indicarea sensului etimonului cruce, adică 'troiță' sau 'intersecție', lucru posibil în urma stabilirii etimologiei toponimice, adică identificarea motivaţiei denominării: fie identificarea unei intersecții sau a unei răspîntii pentru cel de-al doilea sens, fie existența unei troițe în acel loc, așezată acolo în urma unui eveniment (moartea unei persoane) sau prin raportare la o realitate geografică (aşezată lîngă o fîntînă sau o răspîntie). Astfel de informații constituie baza etimologiei toponimice și, în plus, oferă o imagine a modului în care o comunitate se raportează la realitatea înconjurătoare. Din acest ultim punct de vedere, microtoponimia ar putea aspira chiar la un statut științific propriu, ca ramură a disciplinei toponimiei.

Indicațiile etimologice lexicale nu aparţin domeniului toponimiei. Explicații etimologice de ordinul celor sugerate mai sus apar adesea în glosarul de toponime, însă nu sînt resimțite ca necesare în explicația etimologică, ci mai degrabă au statut de informație suplimentară:

LA BĂI, teren pe Valea Vinului, unde s-au făcut amenajări cu scop balnear (Vișeu de Mijloc). Et.: prep. la + subst. pl. băi ,stațiune balneară”.

Desigur, de multe ori informația poate fi doar presupusă, istoria locală fiind puțin rezistentă în timp și supusă adesea reetimologizării, uneori prin trimiterea la legende locale. Referitor la legendele locale, acestea pot fi explicații etimologice reale în cazuri precum cel al toponimului La Comoară.
De multe ori, probabil că de fiecare dată cînd au fost cunoscute, informațiile etimologice toponimice apar în secțiunea anterioară etimologiei, cum ar fi, spre exemplu:

ARȘIŢA BĂLȚII [árșîța bắlțî], deal (Vişeu de Sus). În vîrful dealului se află o baltă cu apă călduță, datorită poziției către soare a dealului. Et.: subst. arşiţă (art.) + subst. baltă (gen.), cu origine incertă în DER, după alți lingviști cuvînt autohton (Brâncuș, 1983, p. 35-37).

Cel mai probabil „vîrful dealului” se referă la partea de sus a dealului, și nu la vîrful propriu-zis, însă existența respectivei bălți este informația necesară unei etimologii toponimice în cazul determinantului din sintagmă. Astfel de informații, chiar dacă nu sînt exploatate la nivelul explicaţiilor etimologice, reprezintă adevărata contribuție etimologică pentru toponimia din zona cercetată. Deplasarea la fața locului și ancheta directă a autoarei aduc informaţii care, în timp, pot fi mai greu de obținut, fie în urma schimbării peisajului geografic (cum ar putea fi cazul pentru exemplul discutat), fie în urma uitării acestora în cadrul comunității respective, cum este cazul informațiilor privind motivarea prezenței unui anumit antroponim în sintagmele toponimice (ceea ce face ca în astfel de cazuri explicațiile etimologice să rămînă cel mai adesea la nivelul lingvistic).

Un alt lucru care derivă din abordarea lingvistică a etimologiei toponimelor, în detrimentul unei etimologii toponimice, este ignorarea neconcordanţei între semnificaţia lexicală a etimonului și caracteristica realității geografice denominate. Fără această concordanță nu poate fi justificat actul denominativ, adică geneza unui nume, etimologia sa. Concret, în exemplul

ARINIȘ [arińíș], pîrîu, afluent al rîului Țișşa (Borșa). Et.: subst. ariniş „pădure de arin" < arin (< lat. alinus $)+$ suf. col. $-i s ̧$,

semnificația „pădure [mică] de arin” indică existența unei mici păduri de arin, nu a unei ape. Hidronimul Ariniş nu poate avea un etimon a cărui semnificație să fie 'pădure'; altfel spus, un pîrîu nu poate fi un ariniş. În schimb, pîrîul poate curge prin apropierea unui ariniş, care are un nume (fitonim) omonim, Ariniş(ul), nume care trece de la această realitate geografică (pădure mică de arin) la o altă realitate 
geografică (un curs de apă) din imediata apropiere. Procesul, numit polarizare, este prezentat detaliat de Moldovanu (1972, p. 78-82), studiu avut în vedere în lucrarea prezentată aici. Astfel, în cazul exemplului citat mai sus trebuie identificat un toponim primar (un fitonim), care are etimologia indicată și care este propriu-zis etimonul pentru hidronim (toponim secundar, polarizat de la toponimul primar). De altfel, acest proces este luat în considerare de autoare în capitolul al cincilea, în cadrul primului tip de clasificare, cel bazat pe semantică, unde se identifică o categorie de „toponime care au ca bază alt nume de loc" (p. 188) și se discută problematica „transferului de nume”. Exemplele utilizate sînt cele frapante, adică sintagmele toponimice formate dintr-un termen geografic (un entopic) și un nume „transferat” (Băile Borșa, Toroioaga Borșa, Culmea Moiseilor etc.). Astfel de cazuri sînt întotdeauna tratate prin raportarea la toponimul primar, dar acest aşa-numit „transfer” este de multe ori ignorat atunci când termenul geografic este subînțeles (Aluniş, Ariniş, Arşiţa ${ }^{1}$ ș.a.). Nu punem accent aici pe modul în care este înțeles „transferul de nume”, însă semnalăm că un transfer presupune identitate formală și funcțională (nu desemnează o realitate geografică dintr-o categorie diferită), ceea ce nu se întîmplă în cazurile date mai sus. Un exemplu de transfer de nume este strada Lizeanu din satul Costișa, comuna Frătăuții Noi, județul Suceava, care este un transfer propriu-zis al numelui străzii Lizeanu din București, sau numele de localități Plevna, Smîrdan, Rahova, Griviţa din România, care sînt un transfer al numelor localităților bulgărești în care au avut loc luptele din timpul Războiului de Independență. Însă nu putem considera a fi un transfer numele străzii Regimentul 11 Siret din Galați, ca și cum numele străzii ar fi un transfer al numelui regimentului (denumirea este motivată de plasarea cazarmei militare pe această stradă pentru o perioadă de timp).

Acelaşi aspect trebuie urmărit atît în cazul în care se identifică toponimul primar, cît și atunci cînd se identifică cel(e) secundar(e), pentru că este necesară o individualizare a acestora, etimologia nefiind una comună. Un exemplu este:

ARȘîȚA ${ }^{2}$ [árșîța], 1. pădure (Moisei); 2. deal; 3. cartier (Vișeu de Sus)...

În afară de problema individualizării, necesară în cazul secțiunilor 2 și 3, este posibil ca secțiunea 1 să nu poată fi tratată în acelaşi loc, dacă este vorba despre o altă arşiţă („parte a muntelui aflată la soare”), una din Moisei.

Un alt aspect de natură semantică important în cadrul "transferului de nume” (în realitate, al polarizării) este semnificația morfologică. Astfel, în contextul discutării „transferului de nume” sînt redate două cîmpuri toponimice, unul pornind de la oronimul Pietrosul, iar celălalt de la oronimul Bătrîna (p. 189). În cel de-al doilea caz trebuie să existe o concordanță de gen între termenul geografic ce poate fi atribuit muntelui și numele Bătrîna, cel mai probabil coastă, cu referire la acea parte a muntelui, dar poate fi vorba şi de o altă realitate geografică, de la care s-a făcut un „transfer de nume”, adică o polarizare. Aceste interpretări diferite sînt valabile și în alte cazuri decît cele menționate mai sus, însă informațiile despre toponimele cuprinse în glosar nu-și pierd valoarea din cauza unor interpretări diferite, uneori în afara perspectivei toponimice.

În penultimul capitol sînt propuse două clasificări ale toponimelor - una bazată pe criteriul semantic, cealaltă pe criteriul formal-și o prezentare a stratificării etimologice (p. 210-221), pe baza observațiilor, dar și interpretări proprii competente, cum este cea pentru Betigi, bazată pe analogia cu explicațiile date de V. Frățilă pentru Bichigi (vezi Betigi, s.v.).

În ultimul capitol, dedicat particularităților lingvistice, se confirmă trăsăturile fonetice specifice graiului maramureșean, cîteva observații la nivelul morfologiei (dintre care se remarcă înregistrarea celor cîteva forme de singular refăcute după plural), precum și la nivelul lexicului.

Contribuțiile lucrării nu se limitează la domeniul toponimiei, deoarece, după cum s-a observat, autoarea abordează întreaga problematică lingvistică şi extralingvistică necesară în cercetarea toponimică.

\section{Bibliografie}

Conea, I. (1969). Toponimia şi cercecarea toponimică în cadrul geografiei, în Îndrumător de cercetări geografice. Cercetări economicogeografice, Societatea de Ştiințe Geografice, Bucureşti, p. 243-247.

Moldovanu, D. (1972). Principii ale lexicografiei toponimice, în „Anuar de lingvistică şi istorie literară”, vol. XXIII, p. 73-100. 